\title{
SISTEM VERTICAL DIGGING, BENCHES ATAU KOMBINASI? MANAKAH YANG DAPAT MEMBERIKAN TINGKAT KEBERHASILAN PALING TINGGI DALAM AKTIVITAS PENAMBANGAN KAPAL KERUK?
}

\author{
Rizki Syafrullah, Gerry Giga Parulian dan Gilang Gunawan
}

Divisi Perencanaan dan Pengendalian Produksi, PT. Timah Tbk

\begin{abstract}
ABSTRAK
Metode penambangan dengan kapal keruk (dredging) termasuk ke dalam metode penambangan tambang terbuka aquaeous, karena mekanismenya yang mirip dengan penambangan pada tambang terbuka, hanya saja kegiatan penggaliannya dilakukan di bawah permukaan air dengan alat penggalian berupa ember (bucket). PT. Timah Tbk sebagai salah satu perusahaan tambang yang memiliki ratusan Izin Usaha Pertambangan (IUP) Operasi Produksi untuk komoditas timah dan sebagai satu-satunya perusahaan yang memiliki beberapa unit kapal keruk, menggunakan armadanya dalam kegiatan penambangan endapan timah alluvial lepas pantai (offshore) di perairan Pulau Bangka dan Kepulauan Riau. Terdapat tiga jenis sistem penggalian pada operasional kapal keruk, yaitu sistem vertical digging, sistem benches dan sistem kombinasi. Sistem penggalian yang digunakan dapat mempengaruhi keberhasilan aktivitas penambangan pada kapal keruk yang dinilai berdasarkan parameter yaitu nilai Laju Pemindahan Tanah (LPT) dan kemiringan lereng (slope) yang dibentuk oleh proses penggalian. Analisis sistem penggalian bertujuan untuk melihat sistem penggalian manakah yang paling tepat untuk diterapkan pada kapal keruk sesuai dengan lokasi kerjanya. Data yang digunakan dalam analisis sistem penggalian merupakan data yang diperoleh langsung selama proses penggalian Kapal Keruk 21 Singkep 1 pada lokasi kerja Bulan Mei 2019. Data tersebut terdiri dari: nilai penekanan ladder, kecepatan naik turun ladder dan kecepatan tarik kawat. Kemudian pengolahan data dilakukan sehingga didapat nilai Laju Pemindahan Tanah (LPT) dan kemiringan lereng (slope) yang terbentuk dari proses penggalian menggunakan ketiga sistem penggalian yang ada. Analisis data dilakukan sehingga didapat poin-poin yang berkenaan dengan kelebihan dan kekurangan masing-masing sistem penggalian. Berdasarkan perbandingan tersebut maka dapat ditentukan sistem penggalian yang paling tepat untuk diterapkan pada Kapal Keruk 21 Singkep 1 sesuai dengan lokasi kerjanya adalah sistem penggalian kombinasi yang memiliki tingkat keberhasilan aktivitas penambangan tertinggi dengan nilai Laju Pemindahan Tanah (LPT) ) yang dapat mancapai target senilai 592,78 $\mathrm{m}^{3} / \mathrm{jam}$ dan kemiringan lereng (slope) akhir $45,83^{\circ}$ yang sesuai dengan standar keamanan penambangan.
\end{abstract}

Kata Kunci: Kapal Keruk, Sistem Penggalian, Laju Pemindahan Tanah, Kemiringan Lereng,

\begin{abstract}
Mining using a dredger is an example of an aqueous open surface mining method. Due to its similarities of mining mechanism to a conventional open surface mining method, the difference being only the digging is carried out below the sea level (underwater) using a series of buckets. PT. Timah Tbk is a mining company that holds hundreds of mining concessions (Izin Usaha Pertambangan / IUP) for tin commodity and is the only company that owns several units of dredger, utilizing their fleet for mining operation of off-shore alluvial tin deposit in the waters of Bangka Island and Riau Archipelago. There are three known digging systems of dredger: vertical digging, benches and combination. These digging systems can affect the success of a dredger's mining operation, which is assessed by following parameters: rate of material removal (Laju Pemindahan Tanah / LPT) and the inclination of slope formed by digging activities. The objective of this analysis on digging system is to find out which system should be applied depending on the
\end{abstract}


dredger's operational location. This analysis processes primary data obtained from digging activity of Kapal Keruk (dredger) 21 - Singkep 1 in May of 2019. The data consists of: ladder pressure, rate of ladder movement and pulling rate of wire. Thereafter, processing of data results in the value of rate of material removal and the slope inclination. Further analysis will disclose the benefits and also the shortcomings of each digging system. Based on acquired and processed data, the digging system that gives the highest rate of success of Kapal Keruk 21 - Singkep 1, which reflected on its rate of material removal of $592.78 \mathrm{~m}^{3} /$ hour and final slope inclination of $45.83^{\circ}$ (conform to the mining safety standard), is the combination system.

Keywords: Dredger, Digging System, Rate of Material Removal, Slope Inclination

\section{A. PENDAHULUAN}

Indonesia merupakan negara yang kaya akan sumber daya alam, antara lain cebakan timah. Jalur timah ini dikenal dengan sebutan sabuk timah Asia Tenggara yang membuat Indonesia menjadi salah satu negara dengan cadangan timah yang besar di dunia .

Kapal Keruk 21 Singkep 1 adalah aset PT. Timah Tbk. untuk penambangan lepas pantai (offshore) yang beroperasi di perairan Bangka dimana merupakan daerah dengan endapan timah terbesar di Indonesia. Kapal keruk adalah kapal yang memiliki rangkaian alat yang berfungsi untuk melakukan penggalian mineral dibawah air seperti bucket, ladder maupun alat-alat penunjang kegiatan penggalian .

Mekanisme penggalian bijih timah yang dilakukan kapal keruk merupakan perpaduan antara pergerakkan rantai mangkok yang mengelilingi ladder seperti halnya rantai pada sepeda. Ladder diturunkan hingga mencapai dasar laut, lalu mangkok yang beregerak pada ladder akan menggali lapisan tanah yang berada di dasar laut, lalu bergerak keatas mengikuti ladder hingga menuju permukaan laut dan akhirnya endapan di tampung pada kapal keruk. Proses penambangan pada kapal keruk dilanjutkan dengan proses pencucian atau mineral dressing yang bertujuan untuk memisahkan mineral timah dari mineral pengotornya dengan menggunakan jig.

Keberhasilan suatu penggalian pada Kapal Keruk dapat diukur dari nilai Laju Pemindahan Tanah (LPT) yang dihasilkan dari aktivitas penggalian yang harus mencapai target sebesar $500 \mathrm{~m}^{3} / \mathrm{jam}$, namun keamanan dari suatu penggalian juga harus dipertimbangkan dengan seksama yang dapat dilihat dari kemiringan lereng (slope) yang terbentuk dari proses penggalian yang harus sesuai dengan ketentuan yaitu $45^{\circ}$.

Penelitian ini menganalisis jenis sistem penggalian pada operasional kapal keruk, yaitu sistem vertical digging, sistem benches dan sistem kombinasi untuk melihat sistem penggalian manakah yang paling tepat diterapkan pada kapal keruk berdasarkan parameter-parameter diatas sesuai dengan Rencana Kerja (RK) bulan Mei 2019 yaitu Laut Air Kantung, Kecamatan Sungailiat, Kabupaten Bangka.

Analisis ini disesuaikan dengan metode penggalian yang digunakan yaitu metode shortface yang membagi lebar kolong kerja menjadi menjadi beberapa irisan dimana dalam hal ini dibagi menjadi 4 irisan dengan lebar setiap irisan $30 \mathrm{~m}$ (3 snee) dan kemajuan penggalian satu trap bernilai 5 meter. Dalam metode shortface Kapal Keruk menggali lapisan tanah pada satu irisan dengan kemajuan penggalian (trap) tertentu baru kemudian berpindah irisan. sebagaimana pada Gambar 1 dibawah ini. Proses penggalian dilakukan satu irisan per satu irisan. 


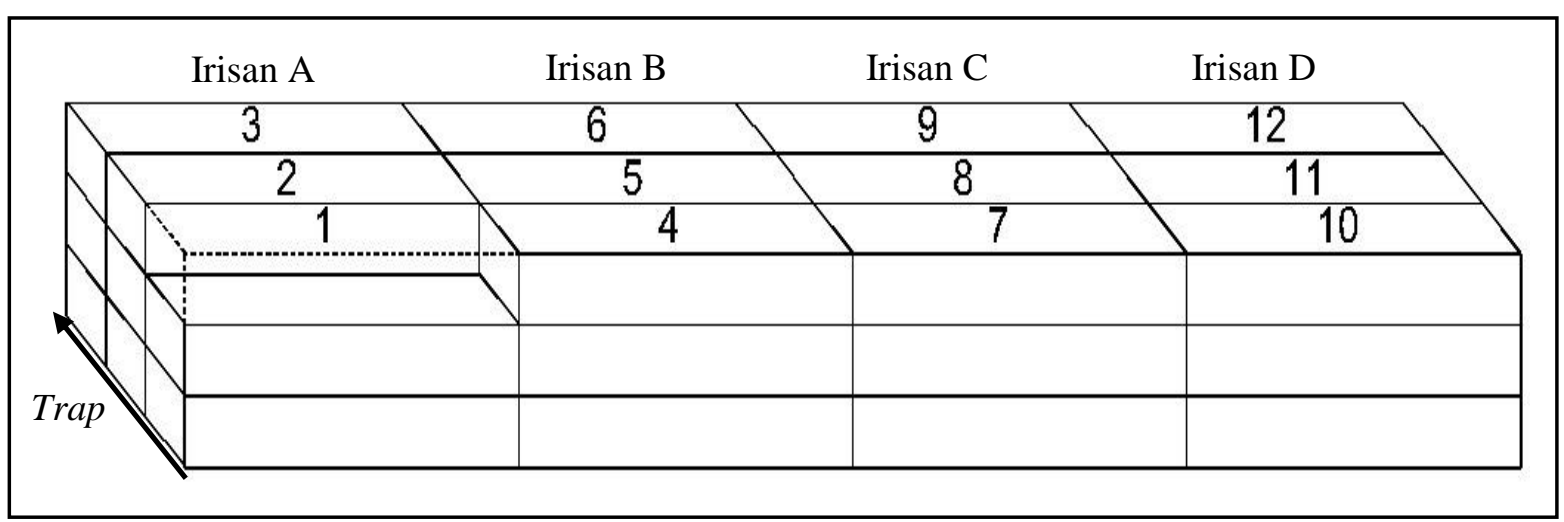

Gambar 1. Sketsa Metode Penggalian Shortface pada KK 21 Singkep 1

\section{B. METODOLOGI PENELITIAN}

Penelitian berlangsung pada Mei 2019. Tahapan penelitian dimulai dari studi literatur untuk memperoleh bahan pustaka dan referensi terkait yang menunjang penelitian dimana dapat berasal dari buku, dan jurnal ilmiah. Studi literatur digunakan sebagai landasan dan pedoman dalam penyelesain masalah yang dirumuskan.

Tahapan penelitian dilanjutkan dengan penelitian langsung ke lapangan yang diawali dengan orientasi lapangan untuk menentukan pengambilan data-data yang diperlukan. Data yang diperlukan terdiri dari data primer dan data sekunder. Data primer yang diperlukan berupa nilai penekanan ladder, kecepatan naik turun ladder, kecepatan tarik kawat pada Kapal Keruk 21 Singkep yang didapat melalui pengamatan langsung dilapangan sebanyak 30 kali sampel untuk setiap jenis data sedangkan data sekunder berupa peta Rencana Kerja (RK) dan spesifikasi kapal Keruk 21 Singkep 1 didapat dari bidang Perencanaan dan Pengendalian Produksi (P2P) Unit Penambangan Laut Bangka (UPLB) PT. Timah Tbk

Data hasil pegamatan sebanyak 30 sampel untuk setiap jenis data disajikan dalam bentuk grafik diikuti garis trennya (Grafik Terlampir Pada Bab Pembahsan). Grafik menunjukkan data yang berdistribusi normal sehingga nilai rata-rata dari hasil pengamtan dapat dijadikan nilai dalam melakukan perhitungan. Perhitungan dilakukan terhadap waktu yang dibutuhkan Kapal Keruk dalam melakukan proses penggalian sesuai Rencana Kerja (RK). Waktu yang diperlukan dalam penggalian didapat dengan menggunakan persamaan seperti dibawah ini :

$$
\mathrm{W}=\frac{H}{d}\left(\frac{d}{v L}+\frac{L}{v G}\right)
$$

Keterangan:

$\mathrm{w}$ = Waktu yang diperlukan untuk penggalian per satu kemajuan muka kerja / 1 trap (menit)

$\mathrm{H}=$ Kedalaman lapisan yang digali, (meter)

$\mathrm{d}=$ Nilai penekanan ladder, (meter/menit)

$\mathrm{vL}=$ Kecepatan penekanan Ladder, (meter/menit)

$\mathrm{L}=$ Lebar permuka kerja / lebar 1 irisan, (meter)

$\mathrm{vG}=$ Kecepatan tarik kawat samping, (meter/menit)

Waktu penggalian per satu kemajuan muka kerja (1 trap) dikalikan dengan banyaknya trap yang digali dalam proses penggalian (sesuai sketsa penggalian pada pembahasan) dan ditambahkan dengan waktu tambahan yaitu:

1. Waktu untuk menaikkan ladder, (meter/menit) 
2. Waktu untuk maju atau mundur kapal, kecepatan tarik kawat haluan dan buritan (meter/menit),

3. Waktu untuk pindah irisan, menggunakan kecepatan Tarik kawat samping (meter/menit),

Sehingga didapat waktu total yang diperlukan dalam penggalian (W).

Waktu untuk melakukan penggalian dengan volume tertentu merupakan nilai Laju Pemindahan Tanah (LPT) yang dapat dihitung dengan persamaan seperti dibawah ini :

$$
\mathrm{LPT}=\frac{\mathrm{VPT}}{\mathrm{W}}
$$

Keterangan:

LPT $=$ Laju Pemindahan Tanah, (m3/jam)

$\mathrm{VPT}=$ Volume Pemindahan Tanah (m3)

$\mathrm{W}=$ Waktu total yang diperlukan dalam penggalian (jam)

Kemiringan lereng (slope) yang terbentuk akibat penerapan sistem penggalian dapat ditentukan dengan persamaan sebagaimana dijelaskan pada Gambar 2 dibawah ini:

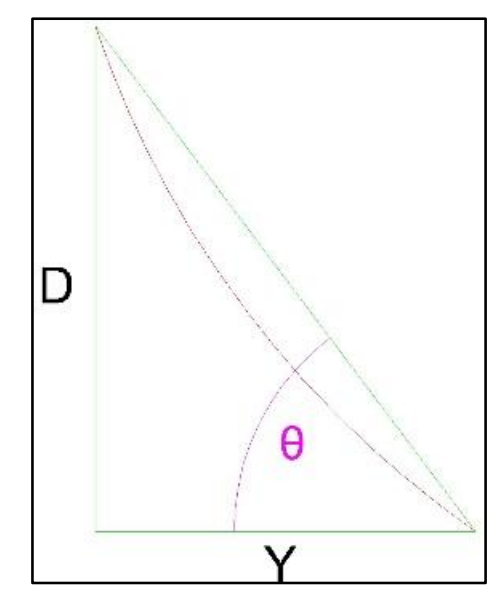

\section{Gambar 2. Sketsa Slope Penggalian pada Kapal Keruk}

$$
\alpha=\tan ^{-1}\left(\frac{\mathrm{D}}{\mathrm{Y}}\right)
$$

\footnotetext{
Keterangan:

$\alpha=$ Sudut Overall Slope

$\mathrm{D}=$ Tinggi Slope

$\mathrm{Y}=$ Lebar Slope
}

Variabel-variabel diatas dihitung berdasarkan Rencana Kerja (RK) Kapal Keruk 21 Singkep 1. Hasil dari pengolahan data tersebut berupa nilai Laju Pemindahan Tanah (LPT) dan kemiringan lereng (slope) masing-masing sistem penggalian.

Analisis dilakukan terhadap nilai-nilai diatas sehingga didapat poin-poin yang berkenaan dengan kelebihan dan kekurangan masing-masing sistem penggalian. Berdasarkan perbandingan tersebut maka dapat ditentukan sistem penggalian yang paling direkomendasikan untuk diterapkan pada Kapal Keruk 21 Singkep 1. 


\section{HASIL PENELITIAN DAN PEMBAHASAN}

Data hasil pengamatan sebanyak 30 sampel untuk setiap jenis dalam bentuk grafik dan garis trennya.

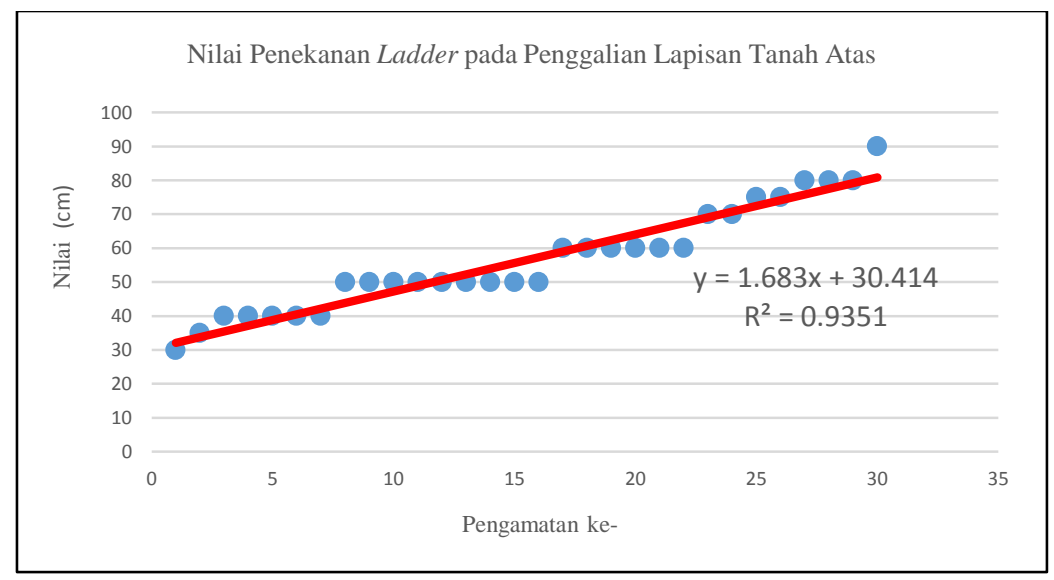

Gambar 3. Grafik Data Nilai Penekanan Ladder pada Penggalian Lapisan Tanah Atas

Dengan Nilai minimum $30 \mathrm{~cm}$ dan nilai maksimum $90 \mathrm{~cm}$ sehingga didapat rata-rata $56 \mathrm{~cm} / 0,56$ $m$ dengan data berdistribusi normal

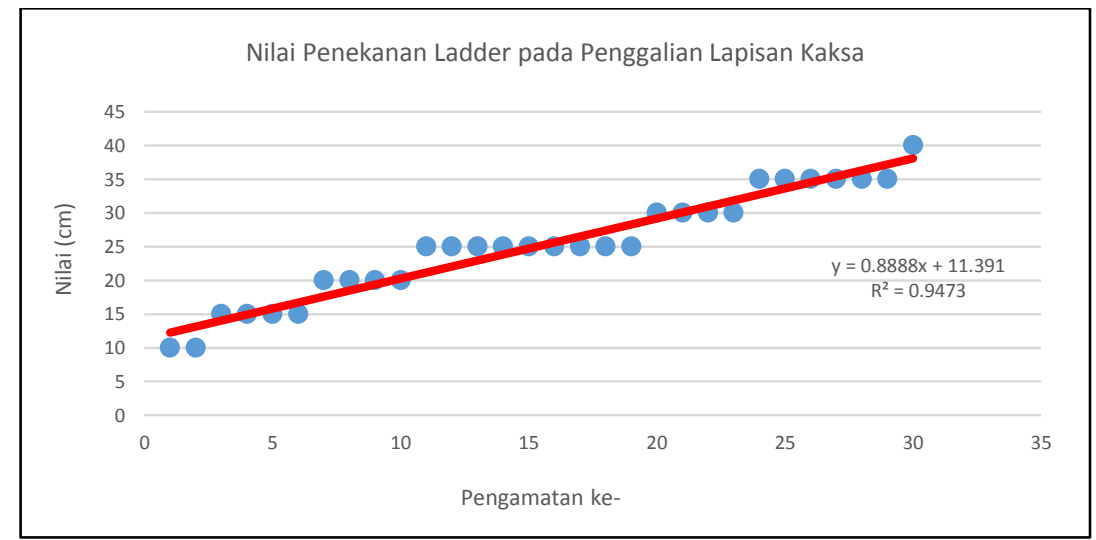

Gambar 4. Grafik Data Nilai Penekanan Ladder pada Penggalian Lapisan Kaksa

Dengan Nilai minimum $10 \mathrm{~cm}$ dan nilai maksimum $40 \mathrm{~cm}$ sehingga didapat rata-rata $25 \mathrm{~cm} / 0,25$ $m$ dengan data berdistribusi normal

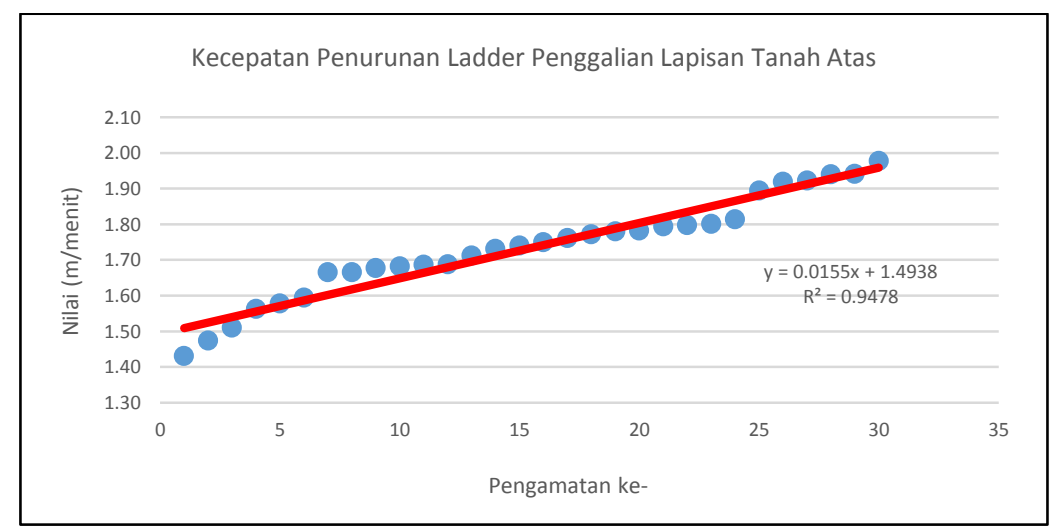


Gambar 5. Grafik Data Kecepatan Penurunan Ladder Penggalian Lapisan Tanah Atas Dengan Nilai minimum 1,43 m/menit dan nilai maksimum 1,98 $\mathrm{m} /$ menit sehingga didapat rata-rata $1,73 \mathrm{~m} / \mathrm{menit}$ dengan data berdistribusi normal

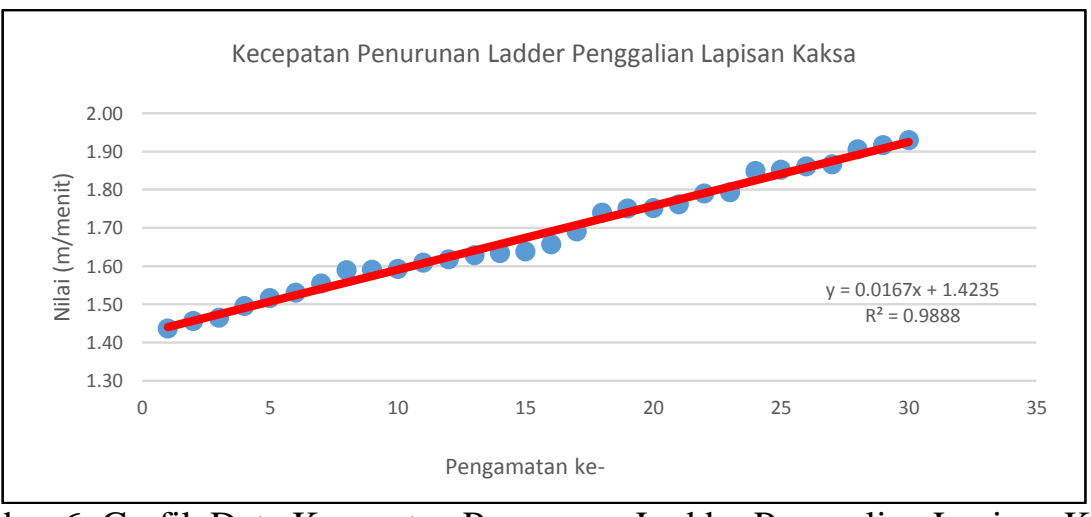

Gambar 6. Grafik Data Kecepatan Penurunan Ladder Penggalian Lapisan Kaksa

Nilai minimum 1,44 m/menit dan nilai maksimum 1,93 m/menit sehingga didapat rata-rata 1,68 $\mathrm{m} /$ menit dengan data berdistribusi normal

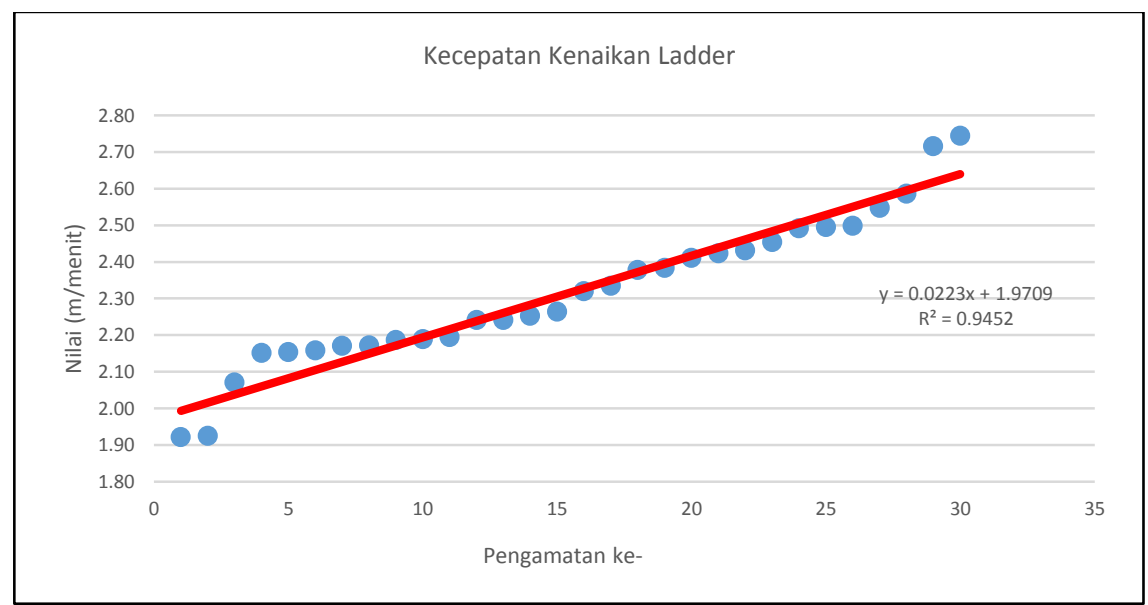

Gambar 7.Grafik Data Kecepatan Kenaikan Ladder

Nilai minimum $1,92 \mathrm{~m} /$ menit dan nilai maksimum $2,74 \mathrm{~m} /$ menit sehingga didapat rata-rata 2,32 $\mathrm{m} /$ menit dengan data berdistribusi normal

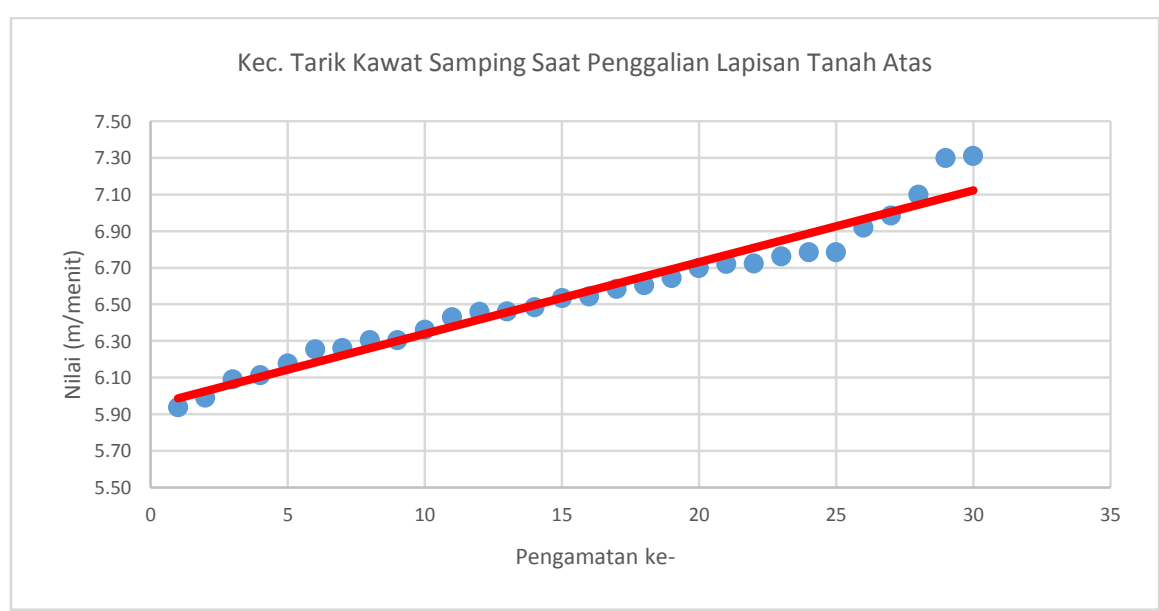

Gambar 8. Grafik Data Kec. Tarik Kawat Samping Saat Penggalian Lapisan Tanah Atas 
Nilai minimum $5,94 \mathrm{~m} /$ menit dan nilai maksimum $7,31 \mathrm{~m} /$ menit sehingga didapat rata-rata 6,55 $\mathrm{m} /$ menit dengan data berdistribusi normal

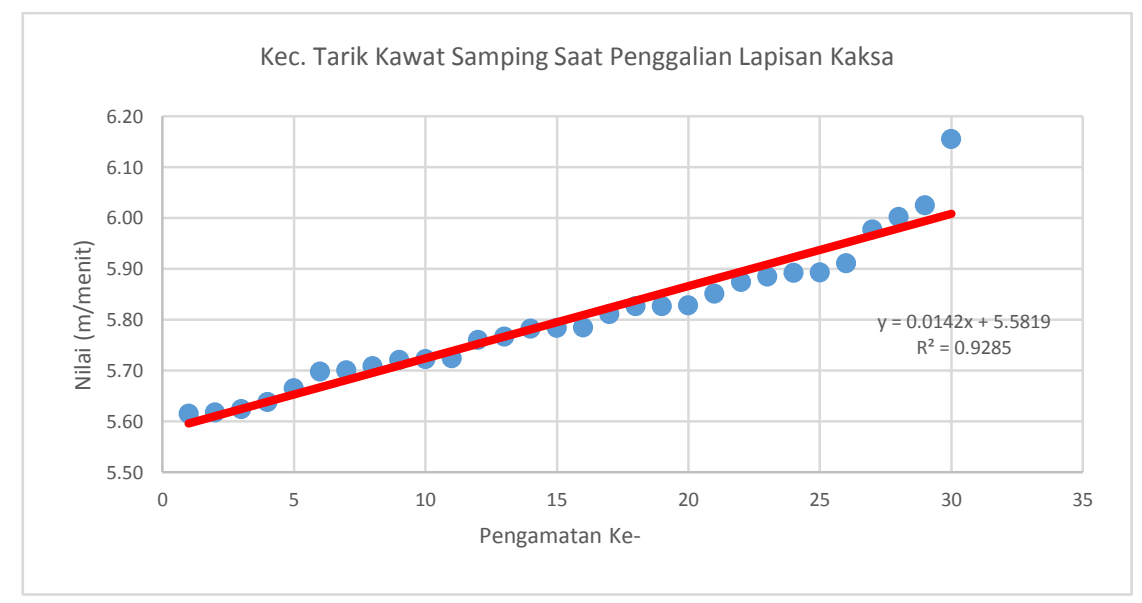

Gambar 9. Grafik Data Kec. Tarik Kawat Samping Saat Penggalian Lapisan Kaksa

Nilai minimum 5,62 m/menit dan nilai maksimum $6,16 \mathrm{~m} /$ menit sehingga didapat rata-rata 5,80 $\mathrm{m} /$ menit dengan data berdistribusi normal

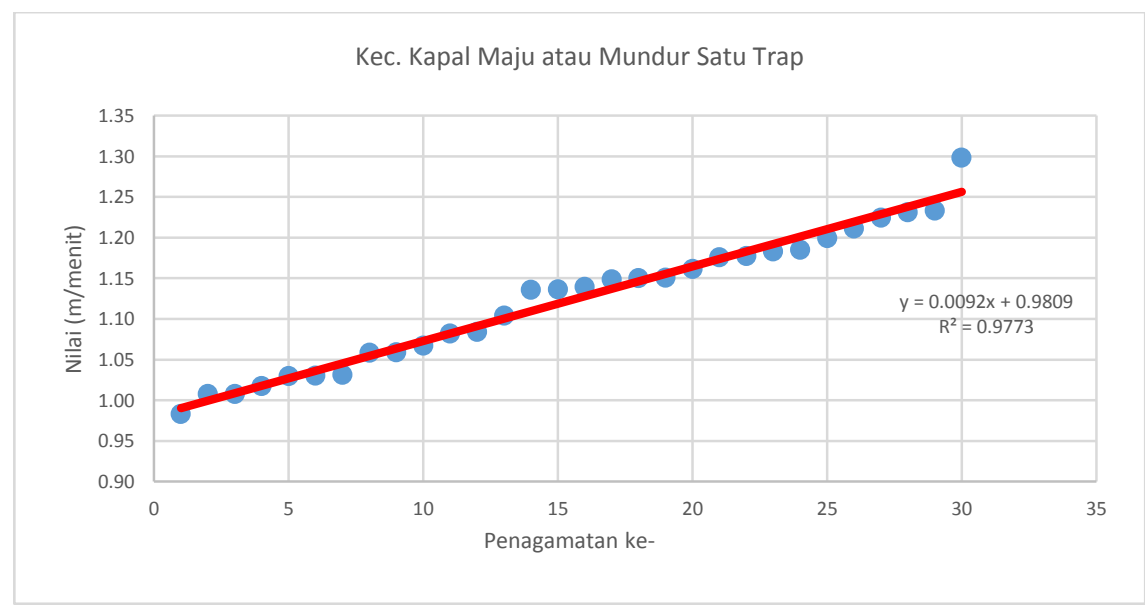

Gambar 10. Grafik Data Kec. Kapal Maju atau Mundur Satu Trap

Nilai minimum 0,98 menit dan nilai maksimum 1,30 menit sehingga didapat rata-rata 1,12 menit dengan data berdistribusi normal

\section{C.1. Sistem Vertical Digging}

Sistem ini menggabungkan lapisan tana atas dan lapisan kaksa menjadi satu lapisan dengan kedalaman $43 \mathrm{~m}$. Sketsa penambangan dari penggalian sistem vertical digging sebagaimana ditunjukkan pada gambar 11 di bawah.

Proses penggalian menggunakan sistem vertical digging dilakukan dengan menggali lapisan tanah secara bertahap dari permukaan lapisan tanah atas, kemudian dilanjutkan dengan menggali lapisan kaksa hingga mencapai batuan dasar/kong. Nilai penekanan ladder untuk lapisan tanah atas dan lapisan kaksa berbeda. Proses penggalian dilakukan dengan kemajuan 3 trap untuk setiap irisan dimulai dari irisan A sampai irisan D. 
Waktu total penggalian dengan sistem vertical digging adalah 7903,86 menit dengan nilai volume penggalian $77.400 \mathrm{~m}^{3}$ sehingga menghasilkan nilai LPT sebesar $598,05 \mathrm{~m}^{3} / \mathrm{jam}$ dan kemiringan lereng penggalian (slope) sebesar $53,55^{\circ}$.

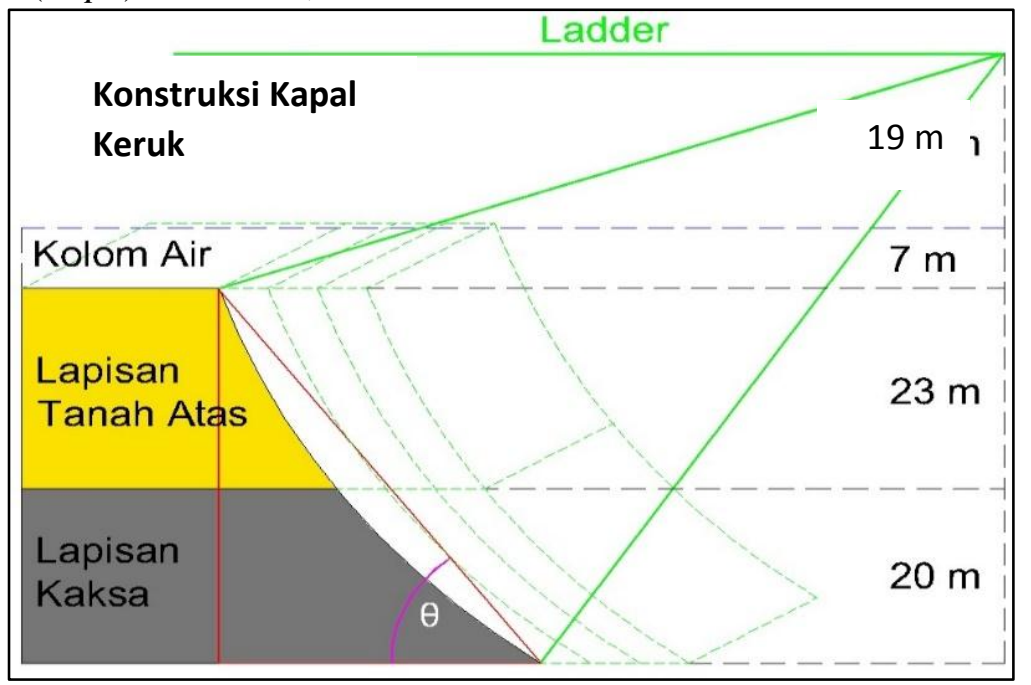

Gambar 11. Sketsa Penggalian Sistem Vertical Digging

\section{C.2. Sistem Benches}

Proses penggalian dengan sistem ini membagi lapisan tanah menjadi 5 lapisan. Lapisan 1, 2 dan 3 merupakan lapisan tanah atas dengan kedalaman masing-masing $8 \mathrm{~m}, 8 \mathrm{~m}$ dan $7 \mathrm{~m}$ sedangkan lapisan 4 dan 5 merupakan lapisan kaksa dengan kedalaman $10 \mathrm{~m}$.

Penggalian dengan kemajuan 3 trap untuk setiap lapisan. Kapal menggali lapisan tanah atas 1 sampai 3 dengan kemajuan 3 trap untuk setiap irisan .Kapal menggali lapisan tanah atas 1 dengan kemajuan 3 trap dari irisan A ke irisan D, lalu mundur dan melakukan penggalian lapisan tanah atas 2 dengan kemajuan yang sama dari irisan D ke irisan A lalu mundur dan melakukan penggalian lapisan tanah atas 3 dengan kemajuan yang sama dari irisan A ke irisan D. Proses penggalian dilanjutkan pada lapisan kaksa setelah lapisan tanah atas untuk setiap irisan selesai digali. Kapal mundur dan melakukan penggalian pada lapisan 4 dari irisan D ke irisan A, lalu mundur lagi untuk melakukan penggalian lapisan 5 dari irisan A ke irisan D.

Waktu total penggalian dengan sistem benches adalah 7765,38 menit dengan nilai volume penggalian $77.400 \mathrm{~m}^{3}$ sehingga menghasilkan nilai LPT sebesar $587,56 \mathrm{~m}^{3} / \mathrm{jam}$ dan kemiringan lereng penggalian (slope) sebesar $39,71^{\circ}$. 


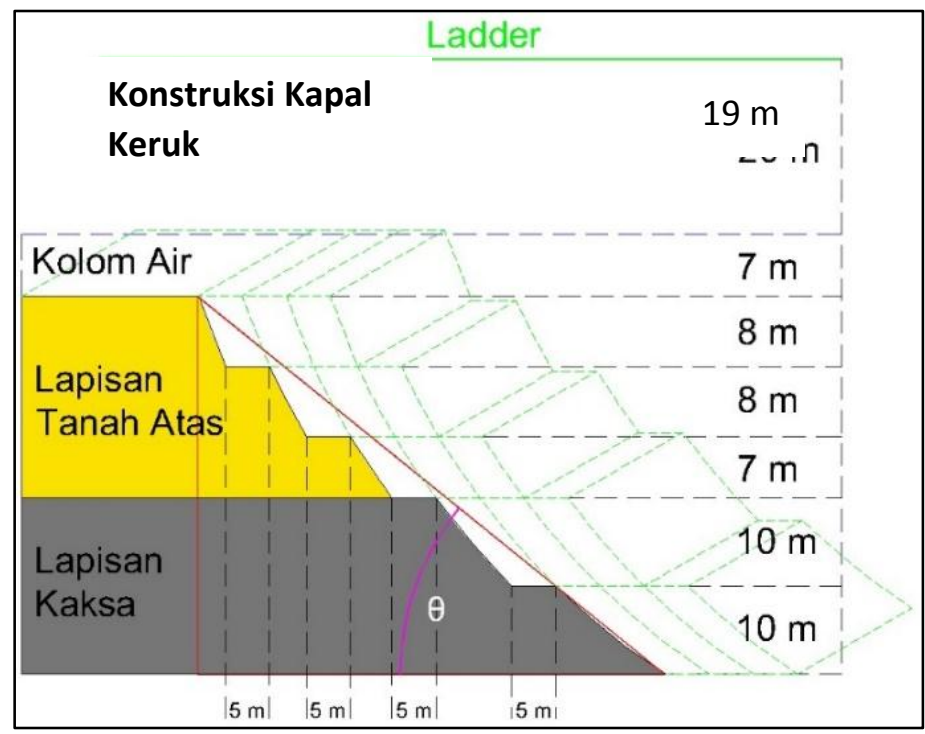

\section{C.3. Kombinasi}

Gambar 12 Sketsa Penggalian Sistem Benches

Proses penggalian dengan sistem ini membagi lapisan tanah menjadi 3 lapisan. Lapisan 1 dan 2 merupakan lapisan tanah atas dengan kedalaman masing-masing $18 \mathrm{~m}$ dan $5 \mathrm{~m}$, sedangkan lapisan 3 merupakan lapisan kaksa dengan kedalaman $20 \mathrm{~m}$.

Penggalian dengan kemajuan 3 trap untuk setiap lapisan. Kapal menggali lapisan tanah atas 1 dengan kemajuan 3 trap mulai dari irisan A ke irisan D, lalu mundur dan melakukan penggalian lapisan tanah atas 2 dengan kemajuan yang sama dari irisan D ke irisan A. Proses penggalian dilanjutkan pada penggalian lapisan kaksa setelah lapisan tanah atas untuk setiap irisan selesai digali. Proses penggalian pada lapisan kaksa dengan kemajuan 3 trap dilakukan dari irisan A hingga irisan D.

Waktu total penggalian dengan sistem kombinasi adalah 7834,20 menit dengan nilai volume penggalian $77.400 \mathrm{~m}^{3}$ sehingga menghasilkan nilai LPT sebesar $592,78 \mathrm{~m}^{3} / \mathrm{jam}$ dan kemiringan lereng penggalian (slope) sebesar $45,83^{\circ}$.

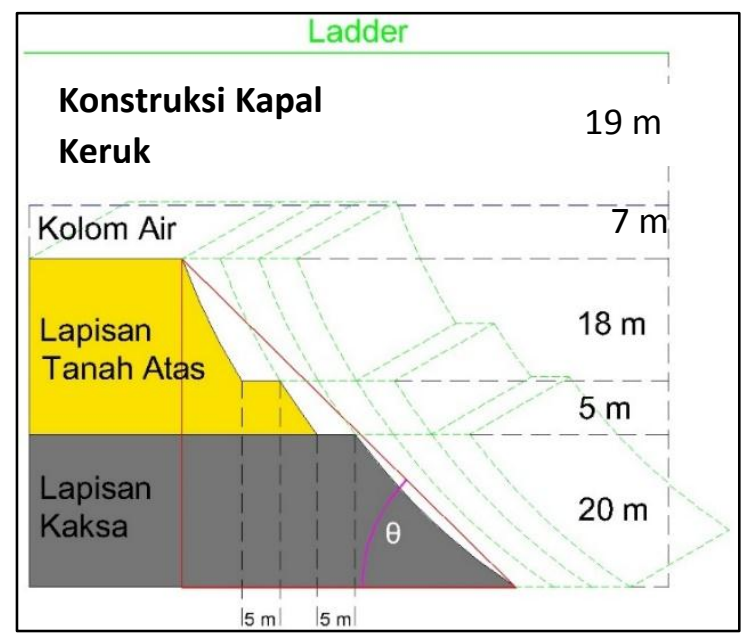

Gambar 13. Sketsa Penggalian Sistem Kombinasi

\section{C.4. Matriks Hasil Penelitian}

Rangkuman penelitian disajikan dalam bentuk matriks sebagaimana ditunjukkan pada Tabel 1.

Tabel 1. Matriks Penelitian 


\begin{tabular}{|c|c|c|c|c|}
\hline $\begin{array}{c}\text { Sistem } \\
\text { Penggalian }\end{array}$ & $\begin{array}{c}\mathbf{L P T} \\
\left(\mathbf{m}^{\mathbf{3}} / \mathbf{j a m}\right)\end{array}$ & $\begin{array}{l}\text { Kemiringan } \\
\text { Lereng/ } \\
\text { Slope } \\
(\alpha) \\
\end{array}$ & Kelebihan & Kekurangan \\
\hline $\begin{array}{l}\text { Sistem } \\
\text { Vertical } \\
\text { Digging }\end{array}$ & $=598,05$ & $53,55^{\circ}$ & $\begin{array}{l}\text { - Proses penggalian } \\
\text { mencapai lapisan } \\
\text { kaksa menjadi lebih } \\
\text { cepat. } \\
\text { - Tidak kehilangan } \\
\text { waktu untuk mundur } \\
\text { kapal sehingga LPT } \\
\text { lebih besar }\end{array}$ & $\begin{array}{l}\text { - Kemiringan lereng (slope) } \\
\text { yang terlalu curam melebihi } \\
\text { ketentuan } \\
\text { - Penggalian lapisan kaksa } \\
\text { menjadi kotor } \\
\text { - Proses pencucian terganggu } \\
\text { dan berdampak pada } \\
\text { penurunan kadar timah yang } \\
\text { dihasilkan } \\
\text { - Resiko terjadinya penggalian } \\
\text { ulang dari material longsor } \\
\text { lebih besar }\end{array}$ \\
\hline $\begin{array}{l}\text { Sistem } \\
\text { Benches }\end{array}$ & $=587,56$ & $39,71^{\circ}$ & $\begin{array}{l}\text { - Penggalian lapisan } \\
\text { kaksa lebih bersih, } \\
\text { - Kemiringan lereng } \\
\text { (slope) yang lebih } \\
\text { landai dari ketentuan } \\
\text { membuat Benches } \\
\text { menjadi sangat kokoh }\end{array}$ & $\begin{array}{l}\text { - Waktu untuk maju dan mundur } \\
\text { kapal lebih banyak sehingga } \\
\text { LPT lebih kecil } \\
\text { - Volume penggalian tanah } \\
\text { untuk pembuatan benches di } \\
\text { awal penggalian lebih besar } \\
\text { - Penggalian terlalu maju } \\
\text { sehingga memungkinkan } \\
\text { material tailing masuk ke } \\
\text { kolong penggalian }\end{array}$ \\
\hline Kombinasi & $=592,78$ & $45,83^{\circ}$ & $\begin{array}{l}\text { Penggalian lapisan } \\
\text { kaksa bersih karena } \\
\text { material longsor tidak } \\
\text { langsung jatuh ke } \\
\text { lapisan kaksa } \\
\text { - Kemiringan lereng } \\
\text { (slope) yang dihasilkan } \\
\text { masih sesuai dengan } \\
\text { ketentuan }\end{array}$ & $\begin{array}{l}\text { - Waktu maju dan mundur kapal } \\
\text { kapal bertambah }\end{array}$ \\
\hline
\end{tabular}

\section{KESIMPULAN}

Berdasarkan hasil penelitian dan pembahasan studi ini, dapat ditarik beberapa kesimpulan antara lain:

1) Berdasarkan matriks diketahui bahwa nilai LPT untuk setiap sistem penggalian menghasilkan nilai yang tidak jauh berbeda dimana semuanya sudah memenuhi target yang ditetapkan yaitu sebesar $500 \mathrm{~m}^{3} / \mathrm{jam}$

2) Kemiringan lereng (slope) untuk setiap sistem penggalian mengahasilkan perbedaan yang cukup besar, dimana hanya 2 sistem penggalian yang dapat memenuhi standar keamanan lereng (slope) yang ditentukan yaitu sistem benches dengan nilai $39,71^{\circ}$ dan sistem kombinasi dengan nilai $45,83^{\circ}$

3) Sistem penggalian yang paling direkomendasikan untuk diterapkan pada lokasi sesuai dengan rencana kerja Mei 2019 adalah sistem kombinasi dengan nilai LPT 592,78 $\mathrm{m}^{3} / \mathrm{jam}$ dan kemiringan lereng (slope) $45,83^{\circ}$ 


\section{DAFTAR PUSTAKA}

Anonim, (2005). Standar Operasi Pencucian KK.. Pangkal Pinang : PT. Timah (Persero) Tbk. Bray, R.N. (1979). Dredging Handbook For Engineers. London:Edward Arnold.

Herbich, J.B. (2000). Removal of Contaminated Sediments by Dredging, Handbook of Coastal Engineering. Newyork: McGraw Hill.

Jusufrusfin, B. (1992). Perkapal Kerukan (Ddredging Tecnique). Pangkalpinang, Bangka : PT. Timah (Persero) Tbk.

Panjaitan, MO. (2014). Tekik Operasi Penggalian Kapal Keruk. Pemali : PT Timah (Persero) Tbk. PT. Timah (Persero) Tbk. (2013). Penambangan Darat dan Laut. Pangkal Pinang: PT. (Timah Persero) Tbk.

PT Timah (Persero) Tbk. (1995).Teknik Pengerukan.Pemali: Pusdiklat PT Timah (Persero) Tbk.

Sujitno, S. (2007). Sejarah Penambangan Timah di Indonesia. Pangkalpinang, Bangka Belitung : PT. Timah (Persero) Tbk

Tim Evaluasi Produksi PT Timah. (2016). Rencana Kerja Kapal Keruk 21 Singkep 1. Laporan Penelitian. Unit Penambangan Laut : PT Timah (Persero Tbk. 
PROSIDING TPT XXVIII PERHAPI 2019 